
under the terms of the Creative Commons Attribution licence (http://creativecommons.org/licenses/by/4.0/), which permits unrestricted re-use, distribution, and reproduction in any medium, provided the original work is properly cited.

doi:10.1017/S0265051716000152 First published online 20 June 2016

\title{
Dropping in and dropping out: experiences of sustaining and ceasing amateur participation in classical music
}

\author{
Stephanie E. Pitts and Katharine Robinson \\ Department of Music, University of Sheffield, 34 Leavygreave Road, Sheffield, S3 7RD \\ s.e.pitts@sheffield.ac.uk, katy.robinson@hotmail.co.uk
}

The benefits of lifelong musical participation have been repeatedly demonstrated through research and anecdote, and yet the challenging question of why more people are not engaged in these activities is rarely addressed. This project used interviews with eighteen current and past amateur ensemble members to explore themes of social acceptance, musical satisfaction and confidence, and to consider how personal determination and circumstances affect adults' continuation of musical activities in the face of competing demands. By understanding how musical participation is viewed by those who no longer engage, or who have had long gaps in their engagement, the research aimed to reconsider the challenges of sustaining participation, and the perceived long-term effects of musical learning and experience. Conclusions are drawn about the role of music education in laying foundations for lifelong participation, and the benefits of providing all children with experience and understanding of making music.

\section{Introduction: perspectives on musical participation}

Recent research on musical participation has documented its many benefits for personal wellbeing, social integration, and musical challenge and satisfaction (e.g. Pitts, 2005; Finnegan, 2007; Hallam et al., 2012). However, the relatively small proportion of the population who maintain their membership of a musical ensemble into adulthood suggests there can be challenges in remaining engaged and motivated once the organised activities of extra-curricular school or college music-making are no longer available (Pitts, 2009; Mantie \& Tucker, 2008). Research with organisations set up to support amateur music making in later life - such as the New Horizons Band movement in America (http://www.newhorizonsmusic.org/) and the East London Late Starters' Orchestra in the UK (http://www.ellso.org/) - has demonstrated the value of ensemble membership for building social networks, and particularly for adjusting to retirement: 'mutual engagement, a supportive environment and conventions and rituals of ensemble performance appear to reinforce older adults' identity constructions' (Dabback, 2008, p. 270). Specifically musical goals were also evident in Dabback's focus group discussions, as New Horizons band members returned to instruments that they had neglected for many years, or took up a band instrument after years of playing solo piano, in order to engage more fully in musical participation (p. 275). In a study with participants in three UK-based community music programmes, Creech et al. (2014) found similarly compelling evidence of the contribution of music to emotional wellbeing and creative satisfaction, concluding that 'even those with little musical background could develop well-understood, rich musical possible selves that 
provided structure, an outlet for autonomous learning and creativity as well as a social context where individuals derived self-confidence and self-esteem' (p. 46).

Adult members of ensembles, particularly those who view themselves primarily as learners, might have distinctive needs in terms of instruction and encouragement, while finding themselves unable to commit to the practice that would allow them to reach their full potential. New Horizons members in Kruse's (2009) study reported that while 'being a band participant had become a positive identity marker for many of the interviewees, the issue of improving musicianship through regular, regimented practice sessions appeared to be a regrettable, incompatible match with their adult lifestyles' (p. 221). Aspects of musicmaking might therefore present themselves to adult players as 'attractive yet unattainable' (p. 215), so requiring a careful match between players and ensembles to achieve a sustainable balance of musical challenge and satisfaction. For adult amateur musicians who do commit to learning new skills (Perkins \& Williamon, 2013) or reviving and developing old ones (Taylor, 2011), the exploration of 'possible musical selves' (Schnare, Maclntyre \& Doucette, 2012) is shown to make a substantial contribution to life satisfaction and wellbeing.

Where researchers have considered the views of those who have chosen not to participate in music after school (e.g. Gavin, 2001; Turton \& Durrant, 2002), they have found a mix of negative attitudes, off-putting experiences and lack of motivation that all contribute to a disinclination to engage in active music-making. However, there has been limited research on a slightly different group of lapsed participants: those who have attempted to continue their musical engagement after school before 'dropping out'. This subtle distinction prompts investigation of the difficulties and dissatisfactions of sustaining musical participation in adulthood, offering a new perspective on the factors that inhibit lifelong musical engagement. Our Arts and Humanities Research Council (AHRC) 'Cultural Value' project sought to address this gap in the research literature by exploring the experiences of players who had currently ceased playing, or who had had a significant break from playing in the past. We aimed to understand how musical participation is viewed from the periphery, exploring the lapsed participants' perspectives on ensemble membership, and considering whether there is a lifelong impact of musical learning even for those adults who no longer participate.

While children's reasons for giving up instruments are relatively well-documented (e.g. Lamont et al., 2003), the factors cited around peer pressure, reluctance to practise and participate, and changes of instrumental teacher might be assumed to apply less to adults, whose circumstances are different and who are drawing on longer experience of playing in making a decision to join an ensemble. Adults' reasons for sustaining or ceasing participation are perhaps closer to those of university students, some of whom seek out the kind of organised musical activities that they enjoyed during school years, making higher education a life stage which presents an 'optimal time for solidifying the potential for viewing active music making as part of a healthy, desirable lifestyle' (Mantie, 2013, p. 53). In related studies with trainee teachers (Kokotsaki, 2010), and music and nonmusic students at university (Kokotsaki \& Hallam, 2011), there are hints of the frustrations that might prevent future adult engagement in music: 'participants being disheartened and overburdened with their music making resulted in reduced perceived ability, lack of enjoyment and withdrawal from the group' (Kokotsaki \& Hallam, 2011, p. 168). Adult 
participants in a retrospective musical life histories study (Pitts, 2012) also reported feeling limited in their abilities through lack of past practice or currently available time, and gained most satisfaction when the ensemble in which they participated was well matched to their current level of ability or the scope of their musical ambition.

Across all age groups, there is relevance in the 'psychological needs' model proposed by Evans, McPherson and Davidson (2013) in their study of why children give up musical learning: 'some students engaged in music activities had strong feelings of needs inhibition - feelings of incompetence, undesirable social outcomes, and pressure - that outweighed fulfilling experiences of competence, relatedness, and autonomy' (p. 615). Taking into account the additional family and work commitments, life changes and time pressures that are cited as reasons to give up comparable activities, such as online learning (Jun, 2005) and sport (Lunn, Kelly \& Fitzpatrick, 2013), it is clear that strong intrinsic motivation is needed to continue musical participation throughout adulthood. Similarly, in her study of Open University students, Castles (2004) observes that the same challenging circumstances will cause some students to drop out while others persist; differences that she attributes to the provision of support, the student's 'love of learning' and the extent to which they are a 'life-challenger' (p. 176).

This project aimed to address the question of how equivalent factors of social support, musical satisfaction and personal determination affect adults' continuation of musical activities in the face of competing demands. By understanding how musical participation is viewed by those who no longer engage, or who have had long gaps in their engagement, the research aimed to reconsider the challenges of sustaining participation, and the perceived long-term effects of musical learning and engagement.

\section{Methods}

A qualitative approach was chosen for this research, since the aim was to understand the lived experience and attitudes of individuals in detail, rather than to document the extent to which ceasing or sustaining musical participation is prevalent in the UK adult population. The main data collection took place through life history interviews (Goodson \& Sikes, 2001), intended to explore people's routes into music, the encouragement and opportunities they had experienced in childhood, and the factors that had led them to cease or continue their musical participation into adulthood (cf. Pitts, 2012). A semi-structured interview schedule covered questions relating to childhood musical participation, continuation or ceasing of music after school and into adulthood, motivations and decisions to participate at different life stages, and memories and regrets around participation. Interviews were recorded and transcribed in full, with the permission of the participants and the ethical approval of the University of Sheffield. The transcripts were then coded thematically to reveal trends across participants and key features of individual narratives, in line with the interpretative phenomenological analysis used in comparable studies of musical participation through the lifespan (McPherson, Davidson \& Faulkner, 2012, p. 92).

Initial recruitment to the study took place through an online questionnaire, designed to gather general overview data to inform the interview questions and to seek volunteers for the second phase of data collection. A mix of multiple choice and open-ended questions 
Table 1. Factors in past and current players' reasons for joining an ensemble.

\begin{tabular}{ll}
\hline \hline Current players $(\mathrm{n}=13)$ & Past players $(\mathrm{n}=7)$ \\
\hline $\begin{array}{l}\text { Thought the ensemble was about the } \\
\text { right level for me (7) }\end{array}$ & Playing with like-minded people (6) \\
Liked the repertoire (6) & Liked the challenge (6) \\
Wanted to meet new friends (6) & Wanted to meet new friends (4) \\
Wanted to play with like-minded people & Liked the particular repertoire of that \\
ensemble (3) & Acquiring new skills (3) \\
Wanted to try something new (3) & Shared faith groups (1) \\
Played when I was younger and wanted & \\
to resume my involvement (3) & \\
Was recruited by a friend/existing & \\
member of the ensemble (2) & \\
Saw a concert and wanted to take part (2)
\end{tabular}

sought to establish the extent and nature of players' past or current playing activities, their reasons for joining and leaving their various ensembles, and their experiences of enjoyment and challenge within rehearsals. The questionnaire was distributed to local amateur orchestras of mixed abilities and ages, with the aim of finding current players who had previously 'lapsed' or who were willing to pass the questionnaire on to former members. Consistent with Lamont's (2011) experience, finding participants willing to reflect on something they no longer do proved challenging, and sustained efforts with social media, word of mouth, and newsletter and website articles over a period of around six months yielded only 20 questionnaire responses: seven from people who no longer played and thirteen who reported previous gaps in participation. Four of these respondents were subsequently interviewed, and a further 14 interviewees were recruited through similar methods but without completing the questionnaire, giving a total of 18 interviewees. The willingness of participants to make the greater time commitment of being interviewed rather than completing a questionnaire suggests that the telling of life stories is more a fruitful direction for this line of research in future studies. However, the 20 questionnaire responses received did help to identify themes for further exploration in the interviews, as detailed in the overview that follows.

\section{Overview of questionnaire findings}

The questionnaire aimed to explore whether motivations for joining an ensemble might be different for those who continue compared to those who cease involvement, but Table 1 shows how the balance of musical, social and personal expectations were broadly similar across the two groups.

Both groups identify the camaraderie of ensemble participation in their search for new friends and like-minded people, and both show an openness to musical challenges in trying something new or acquiring new skills. The main difference is the sense of choice and 'fit' implicit in the current players' highest prioritising of the level of the ensemble 
Table 2. Past and current players' reasons for ceasing or lapsing from musical participation.

\begin{tabular}{|c|c|}
\hline Current players $(\mathrm{n}=13)$ & Past players $(n=7)$ \\
\hline Family commitments (5) & Moved to a new area (3) \\
\hline Moved to a new area (4) & $\begin{array}{l}\text { Change of circumstances (e.g. new job, } \\
\text { family commitments) (3) }\end{array}$ \\
\hline No access to instrument (3) & Time commitment was too demanding (3) \\
\hline Doubts about own musical abilities (2) & Medical circumstances affecting playing (1) \\
\hline Work commitments (2) & Doubts about own musical abilities (1) \\
\hline Medical circumstances (illness/stress) (2) & $\begin{array}{l}\text { No longer eligible to participate (e.g. youth } \\
\text { choirs) (1) }\end{array}$ \\
\hline Fit to ensemble (1) & Financial costs of participating (1) \\
\hline Loss of interest/motivation (1) & \\
\hline
\end{tabular}

being appropriate for them, and so this notion of self-evaluation in relation to the ensemble was a theme pursued further in the interviews.

Motivations for ceasing participation were also open to comparison, within the limitations of the small sample size obtained through the questionnaires. Table 2 shows the reasons given by current and past players for temporary lapses in playing, or the decision to stop participating completely.

Here again it is not the nature of the reasons that is different, but the extent to which they have affected participation, since those cited by the current players were a temporary lapse, whilst the past players had not (or not yet) resumed their playing. Practical circumstances, competing commitments and levels of musical confidence were mentioned by both groups, and so the pertinent research questions relate not only to the factors for ceasing participation, but also the ways in which adult musicians respond to the inevitable pressures upon their commitment to musical activities. The life transition points of leaving home, changing jobs, starting relationships and perhaps a family, and encountering ill health and stress were not surprisingly mentioned in all responses to some degree; the interviews therefore explored further the challenges that these circumstances present for musical participation, and the extent to which participation can be helpful in navigating those life transitions.

Another source of information on reasons for ceasing participation was the current players' responses to the questions 'What (if anything) do you feel could be done to improve your experience of playing with the ensemble(s)?' and 'Is there anything that might cause you to leave the ensemble(s) in the future?'. The answers to the first of these questions related mainly to the quality of music-making, with respondents expressing a desire for longer or more focused rehearsal time, the recruitment of better players, or the time to invest in individual practice between rehearsals. One player summed up the frustration that ensembles would be improved 'if everyone in them could be encouraged to practise more, earlier in the rehearsal schedule rather than only during the week before the concert'. However, the suggested improvements were linked in only two cases to potentially ceasing participation due to 'unrewarding practice or performance sessions': the majority of the 
hypothetical reasons for leaving the ensemble cited the practicalities of available time and the fear of 'old age and arthritis'. A further question is raised, therefore, about the extent to which amateur musicians will tolerate some dissatisfaction in their ensemble playing if this is outweighed by enjoyment (cf. Stebbins, 1992).

With this overview in mind, the interviews will now be explored thematically, analysing the circumstances and attitudes that shaped participants' experiences, and drawing conclusions about how lifelong musical engagement can be beneficial or challenging - and very often both at once.

\section{Thematic analysis of interviews}

The interviewees are introduced with their pseudonyms in Table 3. The sample includes a wide range of ages, levels of musical education and choice of instruments, as well as two interviewees who were educated outside the UK. This variety of perspectives provides rich individual accounts of the many factors affecting lifelong engagement in musical learning and participation, although it is less helpful in identifying trends that might be generalised more widely. In this exploratory study, therefore, the analytical emphasis is on finding the psychological factors that seem to be strongest across the accounts and to categorise these into themes that characterise the experiences of ceasing and continuing adult membership of a musical ensemble.

\section{Conforming or committing: lasting effects of childhood experiences}

Every interviewee had memories of participating in musical ensembles at school or in county ensembles, mainly in orchestras and choirs, with some experiences of chamber music or small pop bands. For some this involvement had been driven by teacher or parent expectation, such as Robert's experience that 'if you played an instrument you were supposed to be in the orchestra', but the majority had been highly motivated by their playing, and reported on the amount and quality of musical activity they had experienced:

Tom: 'There was a reasonable amount going on at my first high school that I went to, and then I moved to another high school, and that was just phenomenal - it was a very small school, and we had two symphony orchestras, a wind band, and they had 30 peripatetic music teachers that would come in and teach, and it was highly, highly valued.'

Daniel: 'I will never forget, actually, the first time I played in an orchestra [...] I was completely knocked out by the ensemble, you know, doing it with others - it's the first time I had played with other people, and it was - I really liked it [...] doing something with a group of other people, together, to make this big noise, I just hadn't ever experienced anything like it, and it really excited me.'

The encouragement and style of the music teacher or band director had affected enjoyment of these early participation experiences, ranging from Daniel's 'charismatic music teacher' to Nigel's 'temperamental' band conductor, who engendered a 'feeling of anxiety and fear 
Table 3. Interview participants.

\begin{tabular}{|c|c|c|c|c|c|}
\hline Pseudonym & Age group & Instrument & Musical education & $\begin{array}{l}\text { Current } \\
\text { player }\end{array}$ & $\begin{array}{l}\text { Past } \\
\text { player }\end{array}$ \\
\hline Brian & $76-85$ & Oboe & $\begin{array}{l}\text { School choir, self-taught } \\
\text { pianist, adult learner of } \\
\text { oboe }\end{array}$ & & $\mathrm{x}$ \\
\hline Mary & $66-75$ & Clarinet & $\begin{array}{l}\text { Childhood piano lessons, } \\
\text { school and college } \\
\text { choir, adult learner of } \\
\text { clarinet }\end{array}$ & & $\mathrm{x}$ \\
\hline Steve & $56-65$ & French horn & $\begin{array}{l}\text { Childhood horn lessons, } \\
\text { school orchestra, } \\
\text { returned to learning as } \\
\text { an adult }\end{array}$ & $x$ & \\
\hline Ian & $56-65$ & Viola & $\begin{array}{l}\text { Childhood piano and } \\
\text { violin lessons, } 16+/ 18+ \\
\text { music exams, music } \\
\text { college, music teacher } \\
\text { training }\end{array}$ & & $x$ \\
\hline Daniel & $56-65$ & Violin & $\begin{array}{l}\text { Childhood violin lessons, } \\
\text { Saturday music school, } \\
\text { university orchestra }\end{array}$ & $x$ & \\
\hline Hannah & $56-65$ & Cello & $\begin{array}{l}\text { Childhood flute and cello } \\
\text { lessons, Saturday music } \\
\text { school, music college }\end{array}$ & $x$ & \\
\hline Ashley & $56-65$ & Keyboard & $\begin{array}{l}\text { Childhood piano lessons, } \\
\text { returned to learning as } \\
\text { an adult }\end{array}$ & $x$ & \\
\hline Gary & $56-65$ & $\begin{array}{l}\text { Tenor horn, } \\
\text { guitar }\end{array}$ & $\begin{array}{l}\text { Childhood piano lessons, } \\
\text { adult learner of guitar, } \\
\text { cello and tenor horn }\end{array}$ & $x$ & \\
\hline Nigel & $46-55$ & Trumpet & $\begin{array}{l}\text { Childhood trumpet } \\
\text { lessons and school } \\
\text { band (US), university } \\
\text { marching band (US) }\end{array}$ & $x$ & \\
\hline Lars & $46-55$ & Trumpet & $\begin{array}{l}\text { Childhood trumpet } \\
\text { lessons and music } \\
\text { school (Netherlands) }\end{array}$ & & $\mathrm{x}$ \\
\hline Tom & $46-55$ & French horn & $\begin{array}{l}\text { Childhood horn lessons } \\
\text { and school orchestras, } \\
16+/ 18+\text { music exams, } \\
\text { music college }\end{array}$ & $x$ & \\
\hline Philip & $46-55$ & Viola & $\begin{array}{l}\text { Childhood viola lessons, } \\
\text { school and youth } \\
\text { orchestras }\end{array}$ & $x$ & \\
\hline
\end{tabular}


Table 3. Continued.

\begin{tabular}{|c|c|c|c|c|c|}
\hline Pseudonym & Age group & Instrument & Musical education & $\begin{array}{l}\text { Current } \\
\text { player }\end{array}$ & $\begin{array}{l}\text { Past } \\
\text { player }\end{array}$ \\
\hline Marcus & $46-55$ & $\begin{array}{c}\text { Clarinet, } \\
\text { oboe }\end{array}$ & $\begin{array}{l}\text { Childhood piano lessons, } \\
\text { adult learner of clarinet } \\
\text { and oboe }\end{array}$ & $x$ & \\
\hline Will & $36-45$ & Cello & $\begin{array}{l}\text { Childhood piano and } \\
\text { cello lessons, school } \\
\text { and youth orchestras, } \\
\text { Saturday music school, } \\
16+/ 18+\text { music exams, } \\
\text { returned to learning as } \\
\text { an adult }\end{array}$ & $x$ & \\
\hline Robert & $36-45$ & Bassoon & $\begin{array}{l}\text { Childhood piano, clarinet } \\
\text { and bassoon lessons, } \\
\text { school orchestra }\end{array}$ & & $x$ \\
\hline Jenny & $26-35$ & Flute & $\begin{array}{l}\text { Childhood flute lessons, } \\
\text { school and university } \\
\text { orchestras }\end{array}$ & & $\mathrm{x}$ \\
\hline Laura & $26-35$ & Clarinet & $\begin{array}{l}\text { Childhood trumpet, } \\
\text { clarinet and saxophone } \\
\text { lessons, school } \\
\text { orchestra and wind } \\
\text { band, university } \\
\text { orchestra }\end{array}$ & & $x$ \\
\hline Rachel & $<25$ & Flute & $\begin{array}{l}\text { Childhood flute and drum } \\
\text { kit lessons, school } \\
\text { orchestra and flute } \\
\text { choir, } 16+/ 18+\text { music } \\
\text { exams, university } \\
\text { orchestra }\end{array}$ & & $x$ \\
\hline
\end{tabular}

about not doing things right' that would later be an off-putting factor in Nigel's decision to join an adult orchestra. Robert's experience of compulsory musical participation in school had left him with 'a very strong sense of classical music as a school thing, if you know what I mean: for me, classical music is very tainted by childhood.' These experiences suggest that the provision of musical opportunities in school was not in itself sufficient to form a lasting connection with music: where this had happened more successfully, factors of intrinsic satisfaction, social enjoyment, and a sense of musical progress and achievement were also firmly in place:

Will: 'the enjoyable thing was playing with other people - and getting into that orchestra and being part of something that's so much bigger. And sometimes it was a bit - when I was right at the back desk and we were playing something really difficult - I found it difficult, that's a bit demoralising. But when you're a kid you kind of, um, 
you know you're going to get better anyway, so you gradually move up the ranks to the second, and eventually, first desk, and then you move up to the bigger orchestra for older and more able kids - which was great.'

While later life transitions (see next section) would prove to be a barrier to continued participation for some respondents, Rachel and Will noted the social currency of transferring to new schools with an established level of musical skill:

Rachel: 'at primary school I was painfully shy, would not talk to anyone, ever, and in the summer before I went to secondary school I was like "I don't want to be painfully shy any more! I want to be more confident!" but then obviously you can't just make yourself - so I joined all the music stuff that I could, I got involved, and obviously, through music, you make friends.'

Will: 'because I didn't know people in the first three years [at my new school] - people had already formed their groups of friends - I felt a bit of an outsider, but I had that music as well, um, to keep me going, and people thought "wow, he's pretty good isn't he!" - so that's what spurred me on to get better at the cello.'

These positive peer relationships through music were also part of adolescent experience for Nigel, who reported that 'a lot of my social life was oriented around the band and the orchestras', and Tom, in whose school 'if anything, you were an oddity if you didn't play an instrument!'. For those who pursued their main musical activities outside school, however, musical identity was less strong amongst their classmates: Hannah, for example, felt that 'it was always something that was seen as "she's going off to do this sort of funny thing," you know'. These formative attitudes about the place and importance of music in everyday life had far-reaching effects for many of the interviewees, shaping their expectations of musical participation as adults in ways that were unlikely to have been anticipated by their teachers, parents and adolescent selves.

\section{Responding to life transitions}

Three of the interviewees (Hannah, Tom and Ian) had chosen to study music in higher education, but each had found music college to be a challenging experience: Tom reported that 'to suddenly be around some absolutely phenomenal people, at first, was really tough', while Hannah was 'miserable, very miserable' and 'didn't like the solitary-ness of having to go home and practise for hours on end on my own, I thought, "this isn't much fun, really"! I didn't feel very good.' This expectation of a relentless practice regime had led several others to reject the music option in favour of another subject: Nigel reported that 'the rumours that were flying around at my school were six hours a day of practice, and I simply couldn't envisage playing the trumpet for six hours a day, you know: an hour, yes, but six hours?' Will had heard similar rumours, and after a consultation lesson that made him realise 'maybe my heart wasn't in it as much as it should be', he decided against applying to a conservatoire: 'I think it put me off that other people could do a lot better than me, and I could only try so hard to make myself a better cellist'. Daniel's decision was 
affected by the disappointment of an unsuccessful audition to the National Youth Orchestra (NYO), but in his case the alternative of a career in medicine was also a strong factor:

Daniel: 'I think had if I got into the NYO, I probably would've carried on. But I didn't, and I thought "right, well I'm not good enough, so I won't," and also my parents suggested that I could make a better living in medicine, and be an amateur musician. But you can't be a professional musician and an amateur doctor! So from the common sense point of view, my father, particularly, suggested that I should pursue medicine, which is what I did. And I do sometimes wonder what would've happened if I hadn't have done that.'

Those interviewees who went to university studying a subject other than music varied in the extent to which they maintained their playing, though most started out with the intention of pursuing new opportunities for participation in this phase of their lives:

Lars: 'I looked around for somewhere to play, 'cos I did enjoy it, and I thought I wanted to continue with it. But it would - I'm not sure I was ready to make the commitment, and I had nowhere to practise. And with the trumpet, that makes it very difficult. And I'd always had issues with neighbours not liking the noise.'

Lars's answer shows how past and future decisions are often embedded in the moment of lapsing from playing: he refers back to his concerns about disturbing the neighbours with his childhood practice, having talked earlier of how he 'had to play with the windows closed, even in high summer', and anticipates a lasting sense of not being ready to commit to an ensemble, which in his current circumstances he links with another practical obstacle, his 'two-hour commute'. In many responses, the citing of a practical reason - time, energy, health - was often the first stage in revealing a more deeply-embedded reason; in Lars's case the readiness to commit to regular rehearsals, which was in turn perhaps reflective of his fairly patchy involvement in group music-making as a child.

Other factors in the school-university transition included confidence and opportunity, which at Nigel's US university meant that the marching band was an easier progression into the higher level of the concert band: 'everyone was able to join the marching band, and I did. It took me another year to get into more serious, classical music ensembles'. Rachel articulated the desire for an experience that replicated her past enjoyment of participation, saying that 'because I enjoyed orchestra so much at school, I wanted the same experience here', and Daniel was particularly fortunate in having a group of friends from school at nearby universities in London, and with a friend who was studying music, 'we set up a smaller chamber orchestra that he conducted, and I led'. However, Rachel was not the only one to be put off by finding that a high standard and established social groups made the experience of playing as an undergraduate quite different from that at school, since there 'there were loads of flutes already and I'm not as good as them [and] it was quite a long way to come [to rehearsals] when I didn't know anyone to begin with'. In her case a shoulder injury and operation compounded her difficulties and she stopped playing for over a year, though at the time of the interview was 'trying to get back to it a little bit'. 
After university, the next transition for many interviewees was moving cities to begin a new job or further studying, and at this stage the most often cited reasons for lapsing were being too busy and not prioritising musical participation. Daniel's working life as a junior doctor meant that he 'was working crazy hours [so] there was no way I could do it, really, and didn't for some years', and Mary, similarly, found that while running a kindergarten and enjoying an active social life 'she was very busy, and I don't think it crossed my mind to look for [an ensemble] really'. First jobs had been stressful for several of the participants, and Jenny, who was faced at the same time with a family bereavement, found that these demands reduced her confidence as a player, stating that 'non-musical circumstances have definitely affected my ability to play'. While work was therefore often in conflict with time and energy for playing, Steve noted its usefulness for other purposes, as for him it had funded his route back into playing: 'as you get further on in your life, you know [...] you get more disposable income: [...] I had an eBay moment one night, randomly looking at French horns on eBay, and I just bought one, and then told my wife!' Others found that music was a welcome distraction from the pressures of work, as described by Nigel who, in a senior university role, spent his days with 'people coming to me for decisions and things like that, and it's actually, it's fantastic, once a week to switch that part of my brain off and go do something and just focus on making music.'

It was anticipated that having young children would be another barrier to participation, particularly for women, but while this was indeed often the case, some interviewees acknowledged that 'if I was passionate about it, I could have got a babysitter, but I didn't do that' (Hannah), suggesting that their new family circumstances changed their priorities as much as their availability. Most saw parenthood as generating a temporary lapse, resuming their involvement once they had 'any energy to do anything' (Philip), or had passed the stage of feeling 'it's not fair to leave [my wife] on her own with a child and then children, while I'm off enjoying myself and playing music!' (Steve). Several players had turned their attention during this phase of their lives to encouraging their children in music, and for Brian this had been an impetus to his own playing: establishing himself as a musical role model he practised his oboe 'diligently, half an hour in the morning and another twenty minutes at night - much to [the family's] annoyance'. Interviewees without children still found their musical choices affected by their relationships, often wanting to give their leisure time to shared activities and so deciding against participation if their partner was not a musician (Nigel), or engaging more for a specific period which 'sort of lapsed when the relationship ended, and there wasn't a piano in the house any more' (Robert).

Several interviewees described movingly how their participation had been affected by bereavement, particularly the loss of their parents. Tom had followed the Orthodox Jewish custom of withdrawing from musical activity for a year after the death of his grandmother, feeling that this was a way of honouring her past encouragement of his music-making: 'in some ways I felt I wouldn't be a musician if it wasn't for her, she was important to my life in many respects, and always encouraging, so it was the fitting and right thing to do'. For Marcus, his father's terminal illness had caused a fairly recent return to playing to feel frivolous, and he found himself not practising and 'making excuses not to go to ensemble':

Marcus: 'Life was beginning to seem a bit trivial - as my dad got iller and iller, everything took a slightly more sombre note, and it was this frivolity that was - "you're 
not even a musician anyway so what do you think you're playing at?" - I think that took hold. So I missed playing, yes, but I also thought, "well, maybe that was something I did for a few years and I got over it".'

Marcus had gradually returned to playing after a break from his ensemble, and when his mother also died a few years later, he found that playing was more of a comfort to him: 'I haven't stopped playing, in fact I've been playing the oboe more, and playing some tunes for my mum'. Marcus's experiences show how the effects of family trauma on musical participation are variable, even for the same person at different times, but they do suggest that motivation, confidence and purpose in music-making, as in many other aspects of life, are brought into question at moments of significant loss and distress.

Having balanced work, family life and other commitments with their musical participation throughout their lives, some of the interviewees looked forward to retirement as a time when they might resume or extend their musical involvement. Lars anticipated that the end of his two hour commuting routine would leave him free 'to do something musical - it may not be a trumpet, I might join a choir', while Steve's story of joining a wind band 'where I wouldn't be too much of a liability because I wasn't really too good' demonstrated how a return to playing could build up until 'I've retired now from work and I still don't have any time because I'm doing so much!' For lan this had not worked out so well, and his decision to rejoin the ensemble of which he had been a founder member in his early career had proved to be frustrating: 'I had this long gap from it, went back into it, and found, technically, I just wasn't up to it'. Other players talked too of the challenges of playing in older age, and both Brian and Mary had recently ceased their ensemble membership at the time of their interviews, carefully balancing their own enjoyment with a responsibility to the ensemble as they decided that they 'might not be doing [things] properly' (Brian) due to declining health or memory.

This tracing of the life-cycle of participation, and its various transition points, highlights how similar opportunities and circumstances are responded to differently by individuals, so that what will for some be an obstacle to participation - such as moving cities or having children - for others becomes a motivation for new musical activities. In the next two thematic sections, we examine more attitudinal aspects of the data, focusing first on the theme of acceptance and confidence, and finally on levels of commitment and passion for music.

\section{Confidence and acceptance: social and musical fit}

Running through the narratives of lapsing from and returning to playing, themes of musical, personal and social confidence recurred, as decisions to join and remain in an ensemble were reinforced or challenged by the musical standard and friendliness of its other members. Those who did seek out an adult ensemble after university, for example, tended to do this as a way to establish themselves in a new location and make friends sharing Philip's view that an amateur ensemble is 'a key into a new community'. However, those seeking social connections through their membership were sometimes disappointed: Laura, for example, had joined a wind band in order to meet new people, but found that 'some of [the members] were welcoming but they already had all their friends, you know', 
with the result that the coffee breaks were 'never very easy', although she 'got on quite well with the people [she] sat next to'. These friendships within sections were mentioned as a common feature of amateur orchestras by some interviewees who had returned to playing, and who found the social aspect of their playing less problematic or important. Tom explained this as a product of the musical respect between players in the horn section of which he is a part: 'horn players tend to be a bit of a fraternity anyway, because we all know the burden [...], we all know how you feel when you're next on the line doing certain things'. While Laura speculated that 'maybe musicians are quite shy in general because they express themselves through their music', other players appeared to find friendliness in their shared playing, without needing this to be developed into a friendship beyond the ensemble. Daniel and Hannah, attending the same orchestra together, enjoyed the 'encouragement' and 'welcome' of their playing colleagues, but Hannah noted that 'we don't have to seek out a social environment when we go to some of the orchestras because we talk to each other'. As Gary explained, 'the social life isn't that good because you go on a Friday night, you get there, say hello, play, goodnight, and then you go home!'

Players differed also in the level of musical challenge that they were seeking from their participation, and where the goals of the ensemble did not appear to match their own, this could become a serious barrier to continued engagement, as in these examples of settings that were too challenging (Mary) or not sufficiently so (Tom):

Mary: '[the new conductor] really raised the standard of the orchestra, and new people joined and all that, and it crept up on me really that I wasn't doing the orchestra any good, and that it would be much nicer if they had a better second clarinettist!'

Tom: 'I was getting bored and not concentrating, and just felt like it wasn't so productive and enjoyable for me. And I'm sure it wasn't pleasant for the other people around me, to suddenly think, "why's he losing interest?"'

Replicating his pattern of joining the more accessible marching band at university, Nigel was tempted out of his lapse in playing by an invitation to join a development orchestra, aimed at adult returners and late starters: 'the ethos is more that the good players really support the weaker players rather than it being [...] something where people are very kind of conscious of status, or ability'. Mary's quote (above) illustrates the difficulties that had arisen for her when the ethos of this ensemble gradually shifted, and the players around her improved at a faster rate than she was able to, although Gary had managed to overcome this by joining a conventional amateur orchestra:

Gary: 'Joining the first amateur orchestra outside that first one was a bit nerve-wracking, but at the same time I was so much in love with the cello - and it made a beautiful sound, it really did - and I thought, "this is superb, I can make a nice sound on it despite my limitations, so sod it, here I am, I'll play to the best of my ability."'

Feeling self-conscious about their own abilities in relation to the players around them was a feature of several other narratives, sometimes to a debilitating extent: 'I never liked tuning up much, I always feel that everyone's listening to you, and everyone's listening 
for whether you've noticed if you're in tune or not' (Jenny). A more experienced player, Hannah nevertheless described the effect that other players had on her own confidence and capabilities:

Hannah: 'if you're sitting next to, or behind, or in front of some very good players, I immediately, my game goes up, and that makes me feel better. [...] I'm not as confident in my playing as I used to be, at all, so I would think to myself, "I can't do this," whereas if I'm sitting with people who are busy doing it, I'Il try and practise a bit and make myself do it, and that feels better.'

Several other players referred to the amount of practice that they were able or willing to do, often feeling that this was not quite enough, while Philip was a lone voice in facing the realisation that he needed to invest more effort in his playing: 'I'm going to need to go and get lessons again, and fix whatever problems I've got, then hopefully I might enjoy it more.' Asked why he would do this rather than seeking out another orchestra, Philip spoke of his sense of responsibility to the ensemble, particularly in relation to his role on the management committee:

Philip: 'I think it's another thing of sort of commitment and duty to the orchestra as well. I think if I just packed it in and walked off, I haven't got succession. [...] So I'm just conscious of needing to hand the baton over - more in terms of management than music - you could easily get another - a better - viola player. Yeah, I mean orchestras are - you know, that's quite, it's a precious thing, you can't just go, "right, we're off."'

By contrast, Hannah and Tom, each of whom had played to a high level before their various lapses, had moved around the various orchestras in their home city and beyond, before settling on the ones that fulfilled their musical needs most satisfactorily. Both explained this restlessness in terms of 'changing levels' (Hannah), and finding a new outlet for their playing after making the decision to cease working professionally in music. After their professional experiences of 'the pressure to do very well' (Hannah) or 'play[ing] this piece, this concert, four times in a week and you have to be as good on each one' (Tom), both were seeking a less pressured but more fulfilling musical experience, and Tom described how 'I think I found what I missed as a young person again - as a student, maybe - you could take risks and it didn't matter, to try different things'. Their perspectives show the range of needs that players bring to an amateur ensemble, from the adult seeking an enjoyable hobby and social night out, to the ex-professional in search of musical thrills and challenges. It is worth noting Laura's observation that for people living in smaller cities or rural areas, the choice of ensembles will be more limited, so making it harder to accommodate the different ambitions and expectations of potential members. Those interviewees who returned most comfortably to musical participation were often drawing on a substantial level of skill and experience, which allowed them not only to make a good choice of ensemble, but also gave them the resources to improve their playing and so increase their sense of involvement and satisfaction:

Will: 'I'd just been faffing about at home, and playing, and seeing if I get up to a reasonable standard again, and wondering what to do with myself, really, where I 
could take it. And my cello teacher that I had in the nineties when I was a teenager she suggested - she was really encouraging me to get into an orchestra, and to get into the Hallam or another orchestra. And I think she asked, um, a couple of people in the cello section, and got me in by that method! So yeah, and I've sold lots of tickets for the last concert, so they were quite happy to keep me on!'

Will joked about his contributions to ticket sales, just as Philip and Steve felt that their roles on the committee compensated for any wrong notes they might play, and in doing so they all hinted at the need to feel accepted and valued within the ensemble. The range of motivations and needs that players bring to their participation make adult ensembles complex organisations, which can seem daunting or demanding for those on the edges of participation.

\section{Commitment to participation: passion, habit or obligation?}

Finally, we examine more closely the ways in which interviewees expressed their commitment to playing, and their own views of their past or current lapses in participation. For some, who had drifted away from an ensemble without thinking very deeply about that choice, the interview was their first attempt to make sense of any gaps in their musical involvement:

Nigel: 'it's kind of incredible to me that it happened, that I put so much time and effort into $[. .$.$] getting to a reasonable standard, and spending all this time participating in$ various ensembles, and you know, to a certain point, I just dropped it.'

This notion of capitalising on investments already made in acquiring musical skill was motivating Rachel to resume playing after her shoulder operation, in response to the 'little nagging feeling in the back of my mind that's saying, "if I just don't continue to play into adulthood - I've lost like ten years of my life!"' Other currently lapsed interviewees felt that this investment had not been so worthwhile and expressed a sense of having acquired the 'wrong' skills for continued participation, and needing 'more skills - not this exam stuff' (Ashley):

Lars: 'I had very thorough classical training, but I never learned to improvise, so I found that very difficult - I needed music to play from. So I think it would have been easier if I'd learnt to improvise, and had learnt to play jazz, basically, would have probably been more helpful.'

Robert: 'there's more context to play the piano, in a way, I mean if you walk into a room there's a piano, and you can sort of play it, and that's kind of - whereas I think bassoons - people don't necessarily want.'

Lars and Robert were both put off by needing 'an orchestra with music' (Lars) in order to make use of their existing skills, whereas for some players, joining an ensemble was the necessary motivation to start practising towards a clear musical goal. 
The experience of resuming playing was in itself no small obstacle to overcome, and there were many stories of the frustration of weak embouchures, slow fingers, and lack of stamina, though generally underpinned by a basic knowledge of the instrument and of musical notation that was still intact. Where motivation was low, or progress was not fast enough, this could sometimes be sufficient to make players put their instruments away again, perhaps feeling 'silly' (Mary) or 'sad' (Rachel) that a cherished skill had been lost. Once again, those with stronger resources to draw on in terms of existing level of skill and strategies for improvement seemed more resilient in their return to playing, as Will found when he was loaned a cello:

Will: 'It was difficult - to start with, I realised how much my fingers had closed up from getting a job where I'm typing all the time. In first position, it was so, so difficult to get back into stretching my hands out, and making the right sound that I wanted to make. Intonation was appalling, actually! [...] It kind of snowballed from there, I suppose, and I started realising that actually I have still got the ability - I mean, the technical ability's not there as much as it was, obviously, because I don't practise bowing for an hour a day and fingering for an hour a day.'

Will's account shows a steady determination to build up his playing again, which in his case was reinforced by a supportive mother, former teacher, and the players in the orchestra that he joined. He describes his first rehearsal as 'fantastic' and 'exciting' and having been 'practising like mad' for it, was spared the sense of 'bewilderment' experienced by Marcus at his first wind ensemble rehearsal: 'I was feeling quite pleased with myself, you know, treble clef, I can see that! And then they started, and within a bar, I was lost. Within a bar.' At his first rehearsal, Nigel was pleasantly surprised by the welcome and encouragement he received, his past experience having led him to expect that 'conductors were just temperamental by nature, and would always go off on a rant'. Some now lapsed participants, however, had found it harder to adjust to the demands of ensemble rehearsing:

Laura: 'we started at half past seven - your lip was dead by the end of it which was quite uncomfortable. Physically demanding, a bit demoralising just watching the clock [...] and it wasn't necessarily putting me in the best mood or leaving me with enough energy to enjoy the weekend.'

The sense of obligation, rather than enjoyment, in Laura's description shows how motivation is a strong factor in giving players the energy to meet the musical demands of rehearsing for a concert. At one end of the spectrum, Tom described how not playing music would 'be like not being able to breathe, almost': he had always intended his lapses to be temporary, and had quickly become in demand as a player once he entered the local amateur circuit, despite feeling that 'I was playing appallingly, you know, judging by critical, professional standards'. Some others, like Will and Steve, had rediscovered a level of enthusiasm that they had had in childhood and adolescence; Daniel and Hannah too, had put considerable effort into finding an orchestra that suited them both, seeking the satisfaction of having 'some incredibly strong emotions playing' (Daniel). Nigel, who had recently resumed playing, expressed a cautious commitment to staying involved for 
the foreseeable future: 'I think now that I'm back into it I'Il keep going with it, I mean it's hard to say, things could change again, but at the moment I, yeah, I do feel committed to it again.' So while some of the continuing participants expressed a sense of obligation to the ensemble, this was in a positive, mutually beneficial sense, without the reluctance or resistance expressed by lapsers like Laura (above).

Within a small sample of this nature, it is hard to show categorically that adult attitudes to participation are shaped in childhood, but there are certainly some strong coincidences: Lars's limited participation at school left him ambivalent about joining an orchestra in adulthood, while Tom's sense of 'being bitten by the bug' drew him back into the amateur scene, almost against his intentions. Steve's adolescent enthusiasm for music was suppressed throughout most of his career, but recurred after his 'eBay moment' and looks set to see him through a fulfilling retirement. Will was directly encouraged by his teenage cello and music teachers, so has resumed his musical identity where he left off at the end of school. Meanwhile, some of those who were less committed adult players talked more of the fun and friendships of their school music-making, and not so much about the musical highlights of specific concerts or repertoire. Only Robert, with his view of classical music having been 'tainted' by school, expressed real regret about the time spent playing music in adolescence, while others articulated the lasting benefits of those activities:

Nigel: 'I think the experience you get playing music, as a musician, is quite different from if you tried to approach it just as someone who listens to it, um, I don't know if it's richer or something in some way, but it's a lived experience.'

Those who had established a passion for music in childhood, and a reasonable foundation of musical skill, seemed to be the best equipped to return to playing later in life; conversely, those who had undertaken musical participation as an expected or required activity in school, were least likely to see it as a potentially valuable part of their adult life.

\section{Conclusions}

There are surely some challenging messages for music educators in these narratives - and even more so in the ones not represented here, of the many young people who have never had the chance to discover that 'there's nothing like making music with other people' (Gary). Of course, there are multiple ways of making that discovery, and the traditional model explored here of instrumental lessons and largely teacher-directed ensemble participation is only one route to lifelong musical engagement; however, it is one which lends itself to a retrospective research approach, having been well-established in schools and a central part of the musical life histories of several generations (Pitts, 2012).

This study has highlighted the many barriers to lifelong musical participation, not least the extent to which other aspects of life get in the way. It has shown too that there is not a straightforward, reliable route from music student to adult amateur musician, but that multiple factors of opportunity, attitude and skill acquisition intersect in unpredictable ways to affect the likelihood of continuing or resuming playing. While school experiences of musical participation had been highly valued by a good number of the interviewees, these were sometimes too strongly associated with teacher-direction, making it harder for 
adults to find equivalent experiences outside those institutional settings. This demonstrates the responsibility of teachers and parents, therefore, to make routes into adult engagement clear, possible and attractive; something that is arguably an even greater concern within the 'band program' structures of US music education (Mantie \& Tucker, 2008), but may be less problematic in the peer learning cultures of popular music (Green, 2002).

There is a suggestion in the interviewees' narratives too that conductors and ensemble members could play a stronger role in understanding the needs and expectations of their players, since a mismatch between personal goals and those of the ensemble was at the route of many decisions to cease participation. In Nigel's development orchestra, where learning and encouragement are prioritised, this articulation of aims seemed to work well, while the faster pace of the ensemble in which Will, Tom, Hannah and Daniel all participate seemed to suit their high level of musical ambition. There are challenges in accommodating ageing or ill players, so that they can retire with satisfaction as Mary and Brian have done, rather than with frustration and regret like lan. Perhaps, too, the 'all or nothing' sense of commitment to an ensemble is unhelpful both for those who are pressured by work, as well as those for whom joining an orchestra feels too big a step. The amateur orchestra is strongly shaped by history and tradition, and the emerging forms of New Horizons Bands (Dabback, 2008) and 'terrible orchestras' (Cottrell, 2014) could be the start of a rebellion against the conventional structures of amateur ensembles. This offers a chance to devise new forms of participation that allow for fluctuating membership and differing musical and personal needs, and that support the social enjoyment of participation more effectively. These alternatives would be unnecessary for many of the current members of existing ensembles, so would need to be established in parallel, but they do present opportunities to broaden access to lifelong musical participation, and so to articulate and demonstrate its benefits more widely.

Continued involvement in musical participation is not the only measure of the value of music education - though it is a neglected measure, and one that deserves to be more prominent in debates about the purpose of music in comprehensive schooling. In this and previous studies (Pitts, 2012), past experiences of learning music, and particularly of learning an instrument, were seen to have lifelong benefits even for those who no longer played. They afforded an insight on music that enhanced experience as a listener, and an opportunity to return to musical engagement that that might lead in new directions in the future. Generating a population that feels a connection with live arts, whether through active engagement or latent support, is a valuable aim for music education, even if it is one that takes decades to realise, and that builds humbly on the work of past generations of music educators rather than making an instant impact.

\section{Acknowledgements}

This project was funded by an Arts and Humanities Research Council Cultural Value research grant $(\mathrm{AH} / \mathrm{L} 005476 / 1)$ and supported by a period of research leave from the University of Sheffield. We are grateful to all our participants for their time and interest in the project, and to members of the Sheffield Performer and Audience Research Centre (SPARC), Lucy Dearn and Sarah Price, for thought-provoking discussions during our research. 


\section{References}

CASTLES, J. (2004) Persistence and the adult learner: factors affecting persistence in Open University students. Active Learning in Higher Education, 5 (2), 166-179

COTTRELL, C. (2014) Orchestras and musical terriblism. Paper at 'Classical music as contemporary sociocultural practice' conference, King's College, London, May 2014.

CREECH, A., HALLAM, S., VARVARIGOU, M., GAUNT, H., MCQUEEN, H. \& PINCAS, A. (2014) The role of musical possible selves in supporting subjective well-being in later life. Music Education Research, 16 (1), 32-49.

DABBACK, W. M. (2008) Identity formation through participation in the Rochester New Horizons Band programme. International Journal of Community Music, 1 (2), 267-286.

EVANS, P., MCPHERSON, G. E. \& DAVIDSON, J. W. (2013) The role of psychological needs in ceasing music and music learning activities. Psychology of Music, 41 (5), 600-619.

FINNEGAN, R. (2007) The Hidden Musicians: Music-making in an English Town (2nd edition). Middletown, CT: Wesleyan University Press.

GAVIN, H. (2001) Reconstructed musical memories and adult expertise. Music Education Research, 3 (1), $51-61$.

GOODSON, I. \& SIKES, P. (2001) Life History Research in Educational Settings. Buckingham: Open University Press.

GREEN, L. (2002) How Popular Musicians Learn. Aldershot: Ashgate.

HALLAM, S., CREECH, A., VARVARIGOU, M. \& MCQUEEN, H. (2012) Perceived benefits of active engagement with making music in community settings. International Journal of Community Music, 5 (2), 155-174.

JUN, J. (2005) Understanding E-dropout? International Journal of E-Learning, 4 (2), 229-240.

KOKOTSAKI, D. (2010) Musical involvement outside school: How important is it for student-teachers in secondary education? British Journal of Music Education, 27 (2), 151-170.

KOKOTSAKI, D. \& HALLAM, S. (2011) The perceived benefits of participative music making for non-music university students: a comparison with music students. Music Education Research, 13 (2), 149-172.

KRUSE, N. B. (2009) An elusive bird: perceptions of music learning among Canadian and American adults. International Journal of Community Music, 2 (2-3), 215-225.

LAMONT, A. (2011) The beat goes on: music education, identity and lifelong learning. Music Education Research, 13 (4), 369-388.

LAMONT, A., HARGREAVES, D. J., MARSHALL, N., \& TARRANT, M. (2003) Young people's music in and out of school. British Journal of Music Education, 20 (3), 229-241.

LUNN, P., KELLY, E. \& FITZPATRICK, N. (2013) Keeping Them in the Game: Taking Up and Dropping Out of Sport and Exercise in Ireland. Dublin: The Economic and Social Research Institute (ESRI). https://www.esri.ie/UserFiles/publications/RS33.pdf [Accessed 20 March, 2014].

MANTIE, R. A. (2013) Structure and agency in university-level recreational music making, Music Education Research. 15 (1), 39-58.

MANTIE, R. \& TUCKER, L. (2008) Closing the gap: does music-making have to stop upon graduation? International Journal of Community Music, 1 (2), 217-227.

MCPHERSON, G. E., DAVIDSON, J. W. \& FAULKNER, R. (2012) Music in our Lives: Rethinking Musical Ability, Development and Identity. New York: Oxford University Press.

PERKINS, R. \& WILLIAMON, A. (2013) Learning to make music in older adulthood: A mixed-methods exploration of impacts on wellbeing. Psychology of Music [published as Online First].

PITTS, S. E. (2005) Valuing Musical Participation. Aldershot: Ashgate.

PITTS, S. E. (2009) Roots and routes in adult musical participation: investigating the impact of home and school on lifelong musical interest and involvement. British Journal of Music Education, 26 (3), 241256. 
PITTS, S. E. (2012) Chances and Choices: Exploring the Impact of Music Education. New York: Oxford University Press.

SCHNARE, B., MACINTYRE, P. \& DOUCETTE, J. (2012) Possible selves as a source of motivation for musicians. Psychology of Music, 40 (1), 94-111.

STEBBINS, R. A. (1992) Amateurs, Professionals, and Serious Leisure. Montreal: McGill-Queen's University Press.

TAYLOR, A. (2011) Continuity, change and mature musical identity construction: Using 'Rivers of Musical Experience' to trace the musical lives of six mature-age keyboard players. British Journal of Music Education, 28 (2), 195-212.

TURTON, A., \& DURRANT, C. (2002) A study of adults' attitudes, perceptions and reflections on their singing experience in secondary school: some implications for music education. British Journal of Music Education, 19 (1), 33-50.

Stephanie Pitts is Professor of Music Education at the University of Sheffield, with research interests in musical participation, arts audiences, and lifelong learning. She is the author of books including Valuing Musical Participation (Ashgate, 2005), Chances and Choices: Exploring the Impact of Music Education (OUP, 2012) and, with Eric Clarke and Nicola Dibben, Music and Mind in Everyday Life (OUP, 2010). An edited book on audiences, Coughing and Clapping (with Karen Burland), was published by Ashgate in 2014. As director of the Sheffield Performer and Audience Research Centre (SPARC), Stephanie is now working with Birmingham Contemporary Music Group and a network of arts organisations on a project about audience experiences of contemporary arts.

Katharine Robinson is a graduate of the BMus and MA Psychology of Music courses at the University of Sheffield, whose research has explored motivations for amateur musical participation across the lifespan. She has been a research assistant on projects relating to provision of music in primary schools, and on the AHRC Cultural Value project based at the Sheffield Performer and Audience Research Centre (http://www.sparc.dept.shef.ac.uk). She now works in the research and evaluation team at Youth Music. 